\title{
Upaya Guru dalam Menangani School Bullying Siswa di Sekolah Dasar
}

\author{
Nurhaedah $^{1}$, Andi Dewi Riang Tati ${ }^{2}$, Irwansyah $^{3}$ \\ ${ }^{123}$ Prodi PGSD, FIP, Universitas Negeri Makassar \\ nurhaedah88@gmail.com
}

\begin{abstract}
ABSTRAK
Penelitian ini bertujuan untuk mendeskripsikan upaya guru wali kelas VI dalam menangani school bullying di SD Negeri Bung. Peneltian ini menggunakan pendekatan kualitatif dengan jenis penelitian kualitatif deskriptif. Penelitian dilakukan di kelas VI SD Negeri Bung dengan sumber data ialah wali kelas VI, korban bullying, pelaku bullying, teman kelas korban dan pelaku bullying, wali korban bullying dan kepala sekolah SD Negeri Bung. Teknik pengumpulan data dilakukan dengan cara observasi, wawancara, dan dokumentasi. Teknik analisis data dilakukan dengan reduksi data, display data, penarikan kesimpulan dan verifikasi. Pengujian keabsahan data dilakuakan dengan perpanjangan pengamatan, meningkatkan ketekunan, dan triangulasi teknik dan sumber. Hasil penelitian menunjukkan bahwa upaya yang dilakukan guru kelas VI dalam menangani bullying fisik seperti di kelas VI SD Negeri Bung ialah menasehati dan menjauhkan bangku korban bullying dari pelaku bullying. Upaya ini tidak berjalan dengan efektif, sehingga bullying fisik masih terjadi. Sedangkan upaya yang dilakukan guru wali kelas VI dalam menangani bullying nonfisik di kelas VI SD Negeri Bung ialah mendiskusikan masalah bullying dengan guru, kepala sekolah, dan orangtua murid. Upaya ini tidak menunjukkan perubahan terhadap bullying nonfisik yang dialami korban bullying. Oleh karena itu dapat disimpulkan bahwa upaya guru kelas VI dalam menangani school bullying belum berjalan dengan baik.
\end{abstract}

Kata Kunci: school bullying, guru, sekolah, orang tua

\section{ABSTRACT}

This study aims to describe the efforts of VI homeroom teacher in handling school bullying at SD Negeri Bung. This study aims to describe the efforts of VI homeroom teacher in handling school bullying at SD Negeri Bung. This research uses a qualitative approach with descriptive qualitative research. The research was conducted in the sixth grade of SD Negeri Bung with data sources such as homeroom teacher VI, victims of bullying, bullying, classmates of victims and bullying perpetrators, guardians of victims of bullying and elementary school principals. Data collection techniques are carried out by observation, interviews, and documentation. The data analysis technique is done by data reduction, data display, drawing conclusions and verification. Testing the validity of the data is done by extending observations, increasing perseverance, and triangulating techniques and sources. The results showed that the efforts made by class VI teachers in dealing with physical bullying as in the sixth grade of SD Negeri Bung were advising and distancing the victims of bullying from the bullying perpetrators. This effort does not work effectively, so physical bullying still occurs. While the efforts made by VI homeroom teacher in dealing with non-physical bullying in SD Negeri Bung VI are discussing bullying issues with teachers, principals, and parents. This effort does not show changes to the non-physical bullying experienced by victims of bullying. Therefore, it can be concluded that the efforts of class VI teachers in handling school bullying have not gone well.

Keywords: school bullying, teacher, school, parent

\section{PENDAHULUAN}

Sekolah dasar merupakan lembaga pendidikan yang menjadi wadah membina generasi penerus bangsa untuk belajar tentang pengetahuan dan pengalaman baru yang berguna dalam kehidupan sehari-hari. Fungsi 
dari jenjang pendidikan dasar adalah untuk membentuk pribadi yang berakhlak mulia, cerdas dan terampil sehingga dapat melanjutkan ke jenjang pendidikan selanjutnya. Hal ini telah diatur dalam Peraturan Menteri Pendidikan Nasional No. 23 Tahun 2006 yang menyatakan bahwa "pendidikan dasar memiliki tujuan untuk meletakkan dasar kecerdasan, pengetahuan, kepribadian, akhlak mulia serta keterampilan untuk hidup mandiri dan mengikuti pendidikan lebih lanjut".

Menurut Pratisto \& dkk, (2014), terdapat tiga unsur tenaga utama yang dimiliki sistem pendidikan di sekolah dasar yaitu tenaga pengajar, tenaga pembimbing, dan tenaga administrasi. Namun pada umumya sekolah dasar tidak memiliki petugas untuk tenaga pembimbing, maka guru kelas harus mengambil peran tersebut dan membekali diri dengan pengetahuan tentang membimbing siswa. Abdurrahman (Syatra, 2013) mengatakan bahwa salah satu tugas guru di sekolah dasar ialah sebagai konselor, dimana sosok guru mampu memberikan nasihat ataupun pelayanan kepada siswa yang memiliki masalah dalam belajar ataupun dalam kehidupan sehari-hari.

Pada umumya usaha membimbing siswa di sekolah biasa disebut dengan istilah bimbingan konseling. Menurut Taufik (Pratisto, 2014:6.4) "bimbingan merupakan suatu usaha untuk memberikan arahan, panduan, nasihat berupa nilai-nilai positif yang bertujuan untuk menuntun ke arah yang lebih baik". Tujuan dan fungsi dari bimbingan di sekolah dasar sangat beragam, salah satunya ialah memberikan layanan bimbingan kepada siswa yang memiliki perilaku menyimpang di sekolah. Salah satu perilaku menyimpang yang menjadi masalah di sekolah saat ini ialah bullying.

Bullying merupakan perilaku negatif yang dilakukan oleh seseorang kepada orang lain secara berulang-ulang dengan tujuan untuk menyakiti perasaan atau fisik orang tersebut. Hal ini terjadi karena adanya kekuatan yang tidak seimbang dimana pelaku bullying jauh lebih kuat daripada korban, baik kekuatan dari segi fisik maupun kekuatan berupa status sosial. Bullying dapat berbentuk seperti pemukulan, penindasan, penghinaan, dan tidak dianggap sebagai bagian dari suatu kelompok. Wiyani (2012) menemukan bahwa siapapun bisa menjadi pelaku bullying di sekolah, baik teman kelas, senior ataupun guru itu sendiri. Lokasi kejadiannya pun bermacam-macam, bisa di dalam kelas kelas, di luar kelas, di sudut-sudut gedung sekolah atau di luar area sekolah yang kurang terawasi.

Kasus bullying sampai saat ini masih sering dianggap sepele oleh pihak sekolah dan belum menjadi prioritas untuk ditangani. Padahal dalam aspek Hukum Perlindungan Anak pasal 54 UU Nomor 35 Tahun 2014 mengatakan bahwa "anak di dalam dan di lingkungan satuan pendidikan wajib mendapatkan perlindungan dari tindak kekerasan fisik, psikis, kejahatan seksual, dan kejahatan lainnya yang dilakukan oleh pendidik, tenaga pendidikan, sesama peserta didik, dan/atau pihak lain". Selain itu, aturan tentang di dalam Undang-undang Perlindungan Anak Pasal 76 C UU No.35 Tahun 2014 juga telah dijelaskan bahwa "setiap orang dilarang menempatkan, membiarkan, melakukan, menyuruh melakukan, atau turut serta melakukan kekerasan terhadap anak".

Dampak dari bullying sendiri sangatlah berbahya. Dampak dalam jangka pendek, Skrzypec (Afroz, 2015) menyatakan bahwa bullying dapat menurunkan tingkat konsentrasi dan perhatian siswa terhadap pembelajaran di kelas. Sedangkan menurut Prasetyo (2011) bullying dapat menyebabkan perasaan tidak aman, depresi, menurunnya kepercayaan diri, menderita stress hinggga munculnya keinginan untuk bunuh diri. Adapun efek jangka panjang bullying menurut Kim (2013) ialah anak yang telah dibully sejak kecil akan mengalami gangguan kesehatan fisik, psikologi, prestasi belajar, dan gangguan dalam bersosialisai. Selain itu, anak yang suka membully temannya sejak kecil akan beresiko menjadi pelaku kriminal atau memiliki perilaku anti sosial di masa depan karena anak dalam umur 4-8 tahun merupakan masa yang sangat krusial bagi perkembangan kesehatan fisik maupun 
jiwanya. Sedangkan menurut Charles Rasion (Prasetyo, 2011) korban bullying dapat mengalami gangguan psikologis Post Traumatic Stress Disorder (PTSD) dan munculnya gangguan seperti rasa cemas yang berlebihan, phobia, dan amnesia singkat pada saat dewasa. Hal ini terjadi karena orang tersebut selalu cemas akan dibully lagi. Selain itu, korban bullying juga berpotensi menjadi pelaku bullying di masa depan, sehingga bullying akan tetap ada dalam kehidupan masyarakat dan di sekolah. Oleh karena itu, bullying harus segera dijauhkan dari kehidupan anak sejak dini untuk mengurangi gangguan dan dampak perilaku menyimpang tersebut.

Kejadian bullying yang fatal sudah sering terjadi di banyak sekolah di Indonesia. Komisi Perlindungan Anak Indonesia mengatakan bahwa telah menerima aduan 26 ribu kasus bullying selama tahun 2011-2017 (Indrawan, 2017). Sedangkan Menteri Sosial Khofifah Indar Parawansa menyatakan bahwa 40 persen anak Indonesia melakukan bunuh diri karena tidak kuat dibully (Liputan6.com, 9 November 2015). Kasus bullying terbaru terjadi di Kudus, dimana seorang siswi kelas empat SD berumur delapan tahun trauma ke sekolah akibat kekerasan fisik berupa pemukulan, diinjak-injak, dan kemaluan korban dimasukkan penggaris besi yang dilakukan oleh geng di kelasnya. Korban telah mengalami kejadian tersebut sejak di kelas tiga SD (Elshinta.com, 31 Juli 2017). Perilaku bullying di sekolah juga sering kali merenggut nyawa korban. Pada tahun 2015, seorang siswa SD berumur 8 tahun di Jakarta meninggal dunia dengan luka di kepala dan dada akibat bullying fisik yang dilakukan oleh temannya (Tribunstyle.com, 18 September 2015).

Penelitian tentang bullying sebelumnya pernah diteliti oleh Widayanti tahun (2009) dengan hasil peneilitian menyatakan bahwa guru masih minim pengetahuan tentang bullying. Penelitian yang serupa juga dilakukan Kusuma (2014) dengan hasil penelitian yang membuktikan bahwa pihak sekolah terutama guru kelas masih memiliki pengetahuan dan kemampuan yang kurang tentang bullying, sehingga banyak kasus bullying di sekolah yang tidak ditangani dengan baik dan akhirnya menimbulkan korban. Selain itu, guru juga bahkan terlibat langsung dalam praktek bullying itu sendiri, dimana guru selalu mengeluarkan kata-kata yang kurang sopan, merendahkan siswa, bahkan melakukan kekerasan fisik terhadap siswa. Berbeda dengan hasil penelitian di atas, Harjiyanti (2017) menemukan bahwa guru kelas dapat menangani bullying di kelas apabila memiliki kemampuan yang baik dalam membimbing siswa yang bermasalah dan berkolaborasi dengan guru bimbingan konseling di sekolah.

Berdasarkan dari uraian masalah di atas, peneliti pun tertarik untuk meneliti tentang kemampuan guru dalam menangani school bullying. Peneliti kemudian melakukan sebuah observasi di SD Negeri Bung, kelurahan Tamalanrea Jaya, Kota Makassar. Peneliti memilih sekolah tersebut karena adanya kabar yang beredar di masyarakat yang tinggal di sekitar sekolah tentang seorang siswa kelas $\mathrm{V}$ yang sering dipukuli oleh temannya pada saat jam sekolah di depan rumah warga. Salah seorang warga sempat merekam kejadian tersebut dengan kamera smartphone yang kemudian diunggah di sosial media facebook.

Selama observasi berlangsung, peneliti mengamati perilaku bullying di kelas $\mathrm{V}$ dan usaha guru kelas dalam menangani masalah tersebut. Siswa yang dicurigai menjadi korban bullying ialah seorang siswa berjenis kelamin laki-laki yang berinisial DN. Siswa tersebut sering dipukuli oleh teman kelasnya hingga dikejar keluar area sekolah. Selain itu, DN juga mendapat perlakuan berupa bullying psikologis, dimana DN tidak diterima baik oleh teman kelasnya sendiri. Bukti ini pun semakin meyakinkan peneliti bahwa DN merupakan korban bullying di kelas V. Kejadian ini telah terjadi berulang-ulang. Guru kelas V mengatakan bahwa kejadian itu memang sering terjadi dan tidak banyak yang bisa dilakukan untuk mengatasi masalah tersebut.

\section{METODE PENELITIAN}

Pendekatan dalam penelitian ini adalah pendekatan kualitatif.objek dalam penelitian ini ialah guru wali kelas VI, korban bullying, pelaku bullying, dan kepala sekolah SD Negeri 
Bung. Teknik pengumpulan data ialah observasi, wawancara, dokumentasi, dan triangulasi. Langkah-langkah dalam menganalisis data ialah yaitu : data reduction, data display, dan conlusion drawing/verification.

\section{HASIL \& PEMBAHASAN}

Hasil penelitian menunjukkan bahwa guru kelas VI belum dapat menangani school bullying dengan baik. Dalam bullying fisik, korban bullying fisik masih mengalami perilaku bullying seperti pemukulan, ditendang, dan pemerasan uang yang dilakukan oleh teman-teman kelasnya, dimana terdapat dua orang menjadi pelaku utama. Bentuk upaya yang dilakukan Ibu HR dengan memisahkan bangku DN serta pemberian hukuman dan nasihat kepada pelaku dan korban bullying rupanya belum efektif menghentikan perilaku bullying di kelas VI. Menurut Pratisto (2014) teguran, nasihat, dan hukuman yang terlalu sering hanya akan memperparah keadaan dan dapat menimbulkan penolakan dan kemarahan pada siswa. Selain itu, Latip (2013) berpendapat bahwa iklim sekolah berupa kerjasama antar guru yang kurang baik dapat menghambat dalam penanganan school bullying. Oleh sebab itu, faktor yang menghambat guru kelas VI dalam penanganan school bullying di kelas VI berasal dari Ibu HR sendiri dan juga iklim sekolah.

Adapun upaya guru kelas VI dalam menangani bullying nonfisik belum berjalan efektif. DN yang menjadi korban bullying nonfisik masih mangalami pengucilan dimana hanya ada dua orang yang mau berteman dengannya. Sedangkan yang lain memilih untuk menjauhinya. Sedangkan gosip serta julukan malas belajar, pencuri jorok semakin memperparah kondisi DN di sekolah. Bentuk upaya yang telah dilakukan Ibu HR dengan melakukan pemanggilan orang tua dan meminta saran dari guru-guru yang pernah mengajar DN. Namun upaya ini belum memberikan pengaruh positif yang siginifikan terhadap perilaku bullying yang diterima DN. Faktor penghambatnya ialah Ibu HR kewalahan menangani banyaknya siswa bermasalah di kelas VI. Selain itu, siswa kelas
VI sudah fokus dalam mempersiapkan diri mengikuti ujian akhir, sehingga Ibu HR tidak terlalu sering menanggapi siswa yang bermasalah, terutama yang mengganggu proses belajar mengajar. kondisi ini pulalah yang menjadi alasan mengapa perilaku bullying yang dialami DN tidak terlalu diindahkan.

Penelitian ini memiliki keterbatasan sebagai berikut:

1. Penelitian sebenarnya dilakukan pada saat korban masih di kelas $\mathrm{V}$ dimana sering mendapatkan kekerasan fisik. Namun karena keterbatasan waktu, peneltian dilakukan pada saat korban di kelas VI dengan wali kelas yang berbeda.

2. Pada saat penelitian berlangsung, wali kelas VI sering izin dari kelas selama hampir dua minggu karena suami yang sedang dirawat di rumah sakit, sehingga menghambat proses penelitian

3. Peneliti tidak sempat menghitung jumlah siswa yang melakukan bullying verbal di kelas VI

\section{KESIMPULAN \& SARAN}

Berdasarkan hasil penelitian dan pembahasan yang telah diuraikan sebelumnya, maka dapat ditarik kesimpulan bahwa upaya guru wali kelas VI dalam menangani school bullying baik dalam menangani bullying fisik maupun bullying nonfisik masih dikategorikan kurang baik dan masih perlu ditingkatan. Hal ini tidak terlepas dari faktor penghambat yang berasal baik dari iklim sekolah maupun upaya dari guru wali kelas VI itu sendiri.

Adapun saran yang dapat peneliti ajukan setelah melakukan penelitian terkait penanganan school bullying di SD Negeri Bung yaitu:

1. Pihak sekolah disarankan untuk membuat program anti bullying untuk mencegah dan mengatasi dampak negatif dari perilaku tersebut terhadap proses belajar mengajar di sekolah dan proses perkembangan peserta didik.

2. Guru kelas hendaknya memperkaya pengetahuan tentang school bullying, kesehatan mental, psikologi abnormal, psikologi kepribadian dan benturan peradaban agar mampu mengatasi masalah bullying pada siswa di kelas, serta selalu menjadi model yang baik 
bagi murid untuk saling menghargai dan menerima kelebihan dan kekurangan setiap individu.

\section{DAFTAR PUSTAKA}

Afroz Jan, Husain Shafqat. 2015. Bullying in Elementry Schools: Its Causes and Effects on Students. Pakistan. Journal of Education and Practice. Vol.6 (19) 43-56

Detiknews, 1 Agustus 2017, Siswi Bunuh Diri karena Dibully, Gubernur Riau: Jangan Terulang. (diakses 6 Maret 2018)

Elshinta.com, 31 Juli 2017, Siswa SD di Gebog, Kudus jadi Korban Bullying. (diakses 6 Maret 2018)

Harjianti Fajarina. 2017. Peran Guru Kelas dalam Menangani Perilaku Bullying pada Kelas IA di SDIT Luqman Al Hakim Internasional. Skripsi. Yogyakarta. Pendidikan Guru Sekolah Dasar Universitas Negeri Yogyakarta

Indrawan, A. A. F. I. F. (2017). KPAI Terima Aduan 26 Ribu Kasus Bully Selama 2011-2017. Retrieved from https://news.detik.com/berita/d3670079/kpai-terima-aduan-26-ribukasus-bully-selama-2011-2017

Kusuma, Monicka Putri. 2014. Perilaku School Bullying pada Siswa Sekolah Dasar Delegan 2, Dinginan, Sumberharjo, Prambanan, Sleman, Yogyakarta. Skripsi. Yogyakarta. Pendidikan Pra Sekolah dan Sekolah Dasar Universitas Negeri Yogyakarta.

Latip, Asep Ediana. 2013. Analisis FaktorFaktor yang Mempengaruhi Bullying pada Peserta Didik Anak Usia

SD/MI. Skripsi. Jakarta. Pusat Penelitian dan Penerbitan Lembaga Penelitian dan Pengabdian Masyarakat UIN Syarif Hidayatullah.

Liputan6.com, 9 November 2015, Mensos: Bunuh Diri Anak Indonesia 40 persen karena Bullying. (diakses 6 Maret 2018)

NEA Human and Civil Rights Center for Advocasy. 2012. Bullying Prevention in Public Schools. Jurnal NEA Education Policy and Practice Center for Great Public Schools.

Oideachais, An Roinn, Scileanna Agus. AntiBullying Procedures for Primary and Post-Primary Schools. 2013. Irlandia. Department of Education and Skills.
(Online), https://www.education.ie/en/ (diakses 4 April 2017)

Papler Debra \& Craig Wendy. 2014. Bullying Prevention and Intervention in The School Environment, Factsheets and Tools. Canada: (Online) PrevNet. https://www.prevnet.ca. (diakses 3 April 2017)

Prasetyo, Eko, Ahmad Baliyo. 2011. Bullying di Sekolah dan Dampaknya bagi Masa Depan Anak. Yogyakarta. Jurnal El - Tarbawi Jurnal Pendidikan Islam, Vol. 4 (1) 19-26

Pratisto Toto, dkk. Perspektif Pendidikan SD. 2014. Tangerang Selatan: Penerbit Universitas Terbuka

Republika, 12 Oktober 2014. KPAI Minta Polisi Usut Video Bullying Beredar (diakses 4 Maret 2017)

Rigby Ken. 2003. Bullying among Young Children, A guide for Teachers and Carers.Adelaide, Australia. Jurnal Australian Government Attorney-General's Department

Storey Kim \& Slaby Ron. 2013. Eyes on Bullying in Early Childhood. USA. Jurnal Education Development Center.

Syatra, Nuni Yusvavera. 2013. Desain Relasi Efektif Guru dan Murid. Jogjakarta: Bukubiru.

Tribunstyle.com, 18 September 2015. Korban Meninggal Akibat Bullying (diakses 6 Maret 2018)

Volpe, Julia Eichhorn, dkk. 2013. Bullying at School: Recomendations for Teachers and Parents.(Online) https://www.education.udel.edu (diakses 3 April 2017)

Wardani, dkk. Perspektif Pendidikan SD. 2014. Tangerang Selatan: Penerbit Universitas Terbuka

Widyawanti, Costrie Ganes. 2009. Fenomena Bullying di Sekolah Dasar Negeri di Semarang. Bandung. Jurnal Psikologi Undip. Fakultas Psikologi Universitas Diponegoro Semarang.

Wiyani, Novan Ardy. 2012. Save Our Children from School Bullying. Jogjakarta: Arruzz Media 